\title{
Estrogen Receptor $\beta$ Participates in Alternariol-Induced Oxidative Stress in Normal Prostate Epithelial Cells
}

\author{
Karolina Kowalska ${ }^{1, * \mathbb{D}}$, Marta Justyna Kozieł ${ }^{1}{ }^{\mathbb{D}}$, Kinga Anna Urbanek ${ }^{1}{ }^{\mathbb{D}}$, \\ Dominika Ewa Habrowska-Górczyńska ${ }^{1}{ }^{\mathbb{D}}$, Kamila Domińska ${ }^{2} \mathbb{D}$ and Agnieszka Wanda Piastowska-Ciesielska ${ }^{1}$ (D) \\ 1 Department of Cell Cultures and Genomic Analysis, Medical University of Lodz, Zeligowskiego 7/9, \\ 90-752 Lodz, Poland; marta.koziel@umed.lodz.pl (M.J.K.); kinga.urbanek@umed.lodz.pl (K.A.U.); \\ dominika.habrowska@umed.lodz.pl (D.E.H.-G.); agnieszka.piastowska@umed.lodz.pl (A.W.P.-C.) \\ 2 Department of Comparative Endocrinology, Medical University of Lodz, Zeligowskiego 7/9, \\ 90-752 Lodz, Poland; kamila.dominska@umed.lodz.pl \\ * Correspondence: karolina.kowalska1@umed.lodz.pl
}

Citation: Kowalska, K.; Kozieł, M.J.; Urbanek, K.A.;

Habrowska-Górczyńska, D.E.;

Domińska, K.; Piastowska-Ciesielska, A.W. Estrogen Receptor $\beta$

Participates in Alternariol-Induced

Oxidative Stress in Normal Prostate

Epithelial Cells. Toxins 2021, 13, 766.

https: / / doi.org/10.3390/

toxins13110766

Received: 6 September 2021

Accepted: 27 October 2021

Published: 29 October 2021

Publisher's Note: MDPI stays neutral with regard to jurisdictional claims in published maps and institutional affiliations.

Copyright: (c) 2021 by the authors. Licensee MDPI, Basel, Switzerland. This article is an open access article distributed under the terms and conditions of the Creative Commons Attribution (CC BY) license (https:/ / creativecommons.org/licenses/by/ $4.0 /)$.

\begin{abstract}
Alternaria toxins are considered as emerging mycotoxins, however their toxicity has not been fully evaluated in humans. Alternariol (AOH), the most prevalent Alternaria mycotoxin, was previously reported to be genotoxic and to affect hormonal balance in cells; however, its direct molecular mechanism is not known. The imbalance in androgen/estrogen ratio as well as chronic inflammation are postulated as factors in prostate diseases. The environmental agents affecting the hormonal balance might participate in prostate carcinogenesis. Thus, this study evaluated the effect of two doses of $\mathrm{AOH}$ on prostate epithelial cells. We observed that $\mathrm{AOH}$ in a dose of $10 \mu \mathrm{M}$ induces oxidative stress, DNA damage and cell cycle arrest and that this effect is partially mediated by estrogen receptor $\beta(\mathrm{ER} \beta)$ whereas the lower tested dose of $\mathrm{AOH}(0.1 \mu \mathrm{M})$ induces only oxidative stress in cells. The modulation of nuclear erythroid-related factor 2 (Nrf2) was observed in response to the higher dose of $\mathrm{AOH}$. The use of selective estrogen receptor $\beta(\mathrm{ER} \beta)$ inhibitor PHTPP revealed that $\mathrm{AOH}$-induced oxidative stress in both tested doses is partially dependent on activation of ER $\beta$, but lack of its activation did not protect cells against $\mathrm{AOH}$-induced ROS production or DNA-damaging effect in case of higher dose of $\mathrm{AOH}(10 \mu \mathrm{M})$. Taken together, this is the first study reporting that $\mathrm{AOH}$ might affect basic processes in normal prostate epithelial cells associated with benign and malignant changes in prostate tissue.
\end{abstract}

Keywords: alternariol; mycotoxin; prostate; oxidative stress; DNA damage

Key Contribution: AOH induces oxidative stress, DNA damage and cell cycle arrest in G2/M cell cycle phase in normal prostate epithelial cells. $\mathrm{AOH}$ affects prostate cells migration, metalloproteinases activity and triggers immune response.

\section{Introduction}

Mycotoxins, as the toxic metabolites of fungi, are present in every day human diets, both in processed as well as unprocessed food. Chronic exposure to mycotoxins represents a global health issue and in recent years a number of studies have been conducted to evaluate and shed more light on how most common mycotoxins might affect human and animal health [1].

Alternariol $(\mathrm{AOH})$ is one of the most abundant mycotoxins produced by Alternaria spp.- - commonly found black mold, affecting food products and buildings [2]. AOH is considered an emerging mycotoxin with safety exposure limits not established yet by the European Food Safety Authority (EFSA) due to insufficient research carried out so far [2]. Nevertheless, $\mathrm{AOH}$ is reported to act as an inhibitor of topoisomerase-an enzyme crucial to the proliferation of cells [3]; it also induces genotoxicity and oxidative stress in cells [4], affects cell cycle and apoptosis in in vitro cell models $[5,6]$. Besides genotoxicity as a main 
concern, $\mathrm{AOH}$ in a dose of $10 \mu \mathrm{M}$ was also reported to modulate the immune response in cells [7]. In addition, it acts as an endocrine disruptor via modulation of androgen receptor (AR) signaling with the half maximal effective concentration (EC50) of $269.4 \mu \mathrm{M}$ [8]. AOH was also reported to possess estrogenic activity similar to phytoestrogen daidzein or the environmental estrogen bisphenol A (BPA) observed in cell-free system with EC50 of $3.1 \mu \mathrm{M} \pm 2.9 \mu \mathrm{M}[9]$. The study also showed that $\mathrm{AOH}$ possess higher binding affinity to $\mathrm{ER} \beta$ rather than ER $\alpha$ [9]. However, data are not consistent though-a mixture of different Alternaria mycotoxins was reported to trigger an anti-estrogenic rather than estrogenic in endometrial cancer cell line Ishikawa treated with $\mathrm{AOH}(0.1-50 \mu \mathrm{g} / \mathrm{mL})$ and $1 \mathrm{nM}$ estradiol (E2) [10]. Thus, it is highly possible that the estrogenic effect of $\mathrm{AOH}$ might be cell typedependent and still it has not been evaluated in prostate epithelial cells.

Oxidative stress is defined as a state of imbalance between production of high energy molecules called reactive oxygen species (ROS), and the respective detoxifying mechanisms [11]. An increased amount of ROS in cells might be associated with activation of various transcription factors including nuclear factor kappa-light-chain-enhancer of activated B cells (NF-kB), nuclear factor erythroid 2-related factor 2 (Nrf2), tumor suppressor p53 and hypoxia inducible factor $1 \alpha(\mathrm{HIF}-1 \alpha)$ [11]; it can also induce DNA damage, disturbances in cell cycle progression and modulation of gene expression. Oxidative stress participates in the two most common prostate diseases: benign prostate hyperplasia (BPH) and prostate cancer (PCa). Both diseases are hormone- and age- related [12]. Modulation of the estrogen and androgen signaling pathway participates in prostate cells proliferation and growth [13]. The androgen/estrogen ratio in prostate tissue is essential, but the role of $E R \beta$ remains questionable. On one hand knockout of $E R \beta$ in mice resulted in decreased proliferation of prostate cells, yet on the other hand, in a prostate cohort study, ER $\beta$ expression was correlated with decreased survival of patients [14]. This fact might be partially associated with different isoforms of $\mathrm{ER} \beta$, which seem to play contradictory roles in prostate tissue.

Nevertheless, environmental agents which might affect testosterone/estrogen ratio in prostate tissue may also participate in inflammation or carcinogenesis in the prostate. As mentioned before, $\mathrm{AOH}$ was reported to both affect $\mathrm{AR}$ and $\mathrm{ER} \beta[8,15]$, and it is possible that the linking molecular pathway associated with these effects is induction of oxidative stress in cells. Thus, the aim of the study was firstly to evaluate the effect of $\mathrm{AOH}$ on the induction of oxidative stress in normal prostate cell line PNT1A and secondly to check if it is associated with the activation of $\mathrm{ER} \beta$. We observed that $\mathrm{AOH}$ induces oxidative stress, DNA damage, and cell cycle arrest in G2/M cell cycle phase in normal prostate epithelial cells. Moreover, AOH affects prostate cells migration, metalloproteinases activity and triggers immune response.

\section{Results}

\subsection{AOH Significantly Affects Viability of Prostate Epithelial Cells}

Firstly, the effect of AOH on PNT1A cell was evaluated in a dose- and time- dependent manner (Figure 1A). It was observed that $\mathrm{AOH}$ in a dose range between 10 and 100 $\mu \mathrm{M}$ significantly influenced the viability of prostate epithelial cells (*** $p<0.001$ ), while concentrations below $10 \mu \mathrm{M}$ caused no effect, both after 24 and $48 \mathrm{~h}$. Based on these results, the lowest dose of $\mathrm{AOH}$ for which the decrease in cell viability $(10 \mu \mathrm{M})$ and a dose for which no decrease was observed were chosen for the rest of experiment as a higher dose $(10 \mu \mathrm{M})$ and a lower dose $(0.1 \mu \mathrm{M})$ of $\mathrm{AOH}$, respectively. Then, the cell viability was once again evaluated to verify if ER $\beta$ is involved in the viability reduction caused by AOH (Figure 1B). Treatment of PNT1A cells with $10 \mu \mathrm{M}$ AOH and ER $\beta$ inhibitor PHTPP also caused decrease in cell viability as compared to cells treated only with PHTPP, however the decrease was significantly smaller compared to $\mathrm{AOH}$ treatment alone $\left({ }^{* * *} p<0.001\right)$. A similar effect was observed for higher dose of $\mathrm{AOH}\left({ }^{*} p<0.05\right)$. Estradiol (E2) in physiological concentration has no effect on PNT1A cell viability. The observed changes in cell viability were also 
reflected in cell morphology (Figure 1C)—cells treated with higher dose of $\mathrm{AOH}$ showed increased visibility of nuclei and contracted cell shape.

A

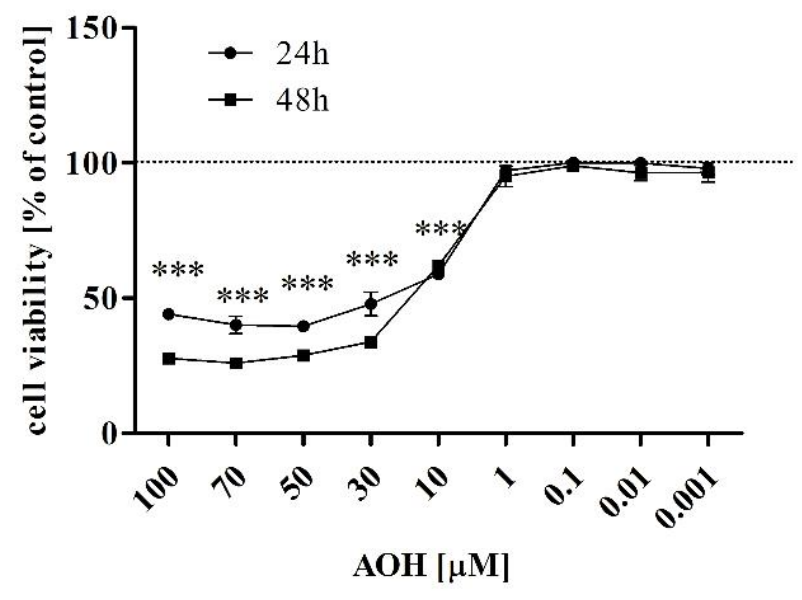

$\mathrm{C}$

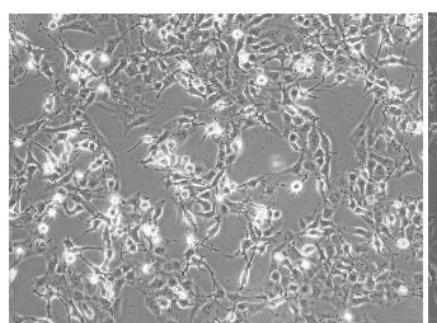

$10 \mu \mathrm{M} \mathrm{AOH}$

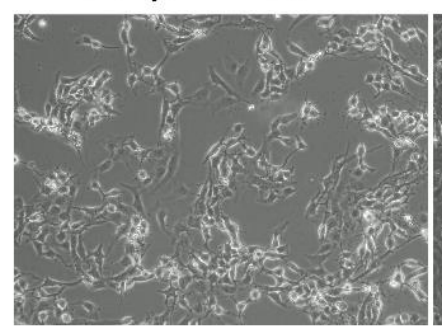

\section{$10 \mu \mathrm{M} \mathrm{AOH}$ + PHTPP}

B
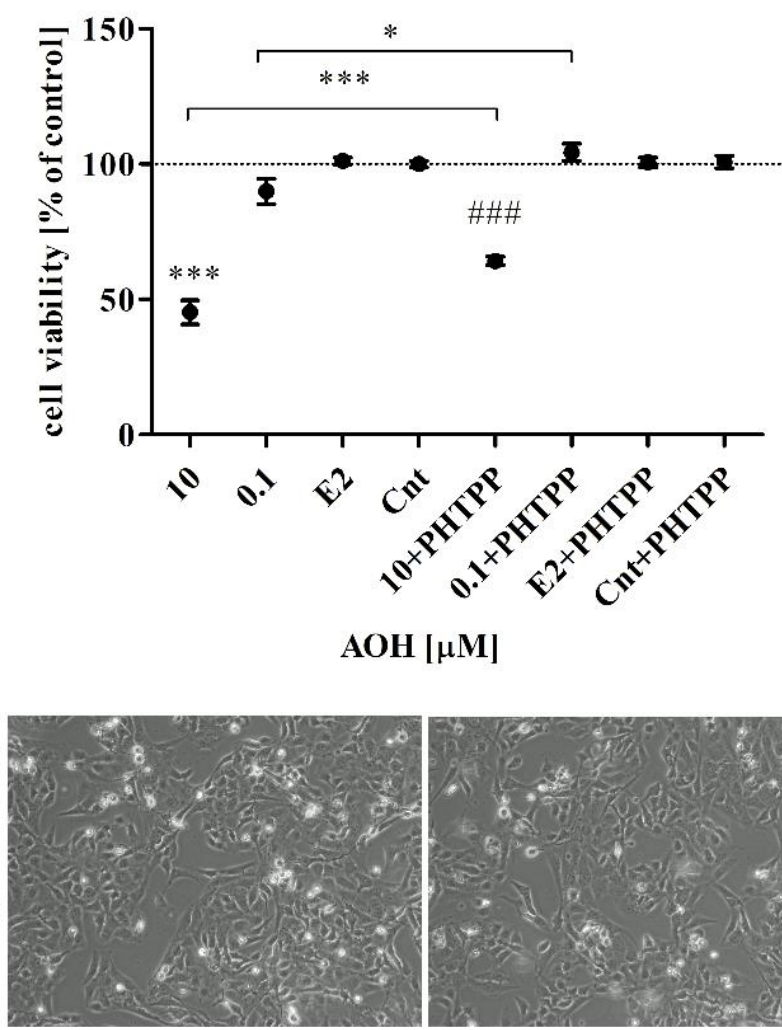

E2

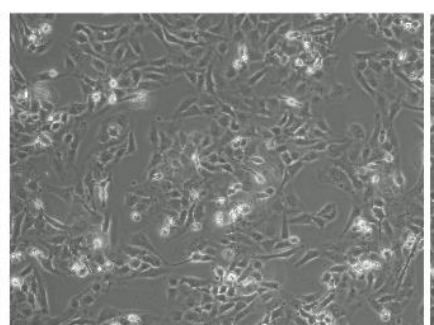

$\mathrm{E} 2+$ PHTPP

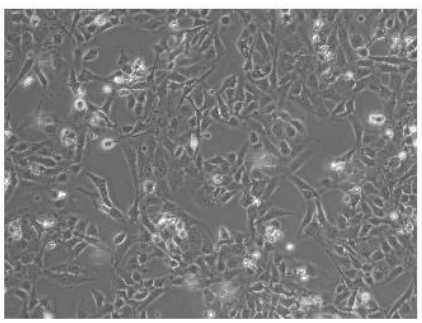

Cnt

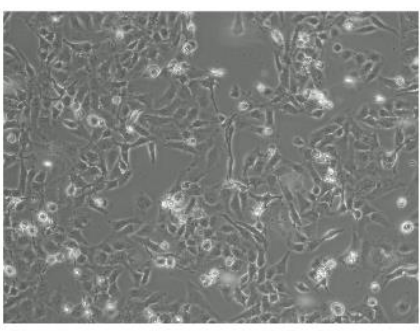

Cnt + PHTPP

Figure 1. AOH affects viability of prostate epithelial cells. (A) The dose-dependent viability curve obtained after 24 and $48 \mathrm{~h}$. (B) Cells viability results after $24 \mathrm{~h}$. The viability was evaluated with Alamar Blue ${ }^{\circledR}$ assay. The results are expressed as mean \pm SE. $p$ value lower than 0.05 was considered as statistically significant. One-way ANOVA was used for statistical analysis. (C) Morphological changes in cells observed after $24 \mathrm{~h}$ in optical microscope, magnitude $100 \times$. ${ }^{*} p<0.05,{ }^{* * *} p<0.001$ as compared to control, \#\# $p<0.001$ as compared to Cnt PHTPP. AOH—alternariol, PHTPP—ER $\beta$ inhibitor, Cnt—control. The cell viability assay was carried out in 6 replications.

\subsection{AOH Induces Oxidative Stress in PNT1A Cells}

In the next part of experiment we evaluated if the decreased viability of PNT1A cells is associated with oxidative stress and DNA damage. Firstly, we observed, as assumed, that $\mathrm{AOH}$ induces oxidative stress in PNT1A cells in a dose-dependent manner (Figure 2A). Similarly to the changes in the viability results, blocking of ER $\beta$ with PHTPP caused decrease in generation of ROS as compared to cell treated only with $\mathrm{AOH}$ for both doses used 
in the experiment ${ }^{* * *} p<0.001$ and ${ }^{* *} p<0.01$, respectively for $10 \mu \mathrm{M}$ and $\left.0.1 \mu \mathrm{M} \mathrm{AOH}\right)$. However, inhibition of ER $\beta$ was not sufficient to protects cells against $\mathrm{AOH}$ induced generation of ROS. The induction of oxidative stress was also associated with the modulation of superoxide dismutase 1 (SOD1) expression on gene and protein level (Figure 2B). An increased expression of SOD-1 was observed after treatment with $10 \mu \mathrm{M} \mathrm{AOH}$ as compared to control, whereas a contradictory effect was observed for treatment with AOH + PHTPP as compared to Cnt + PHTPP. For the lower dose a similar but smaller effect was observed (Table 1).

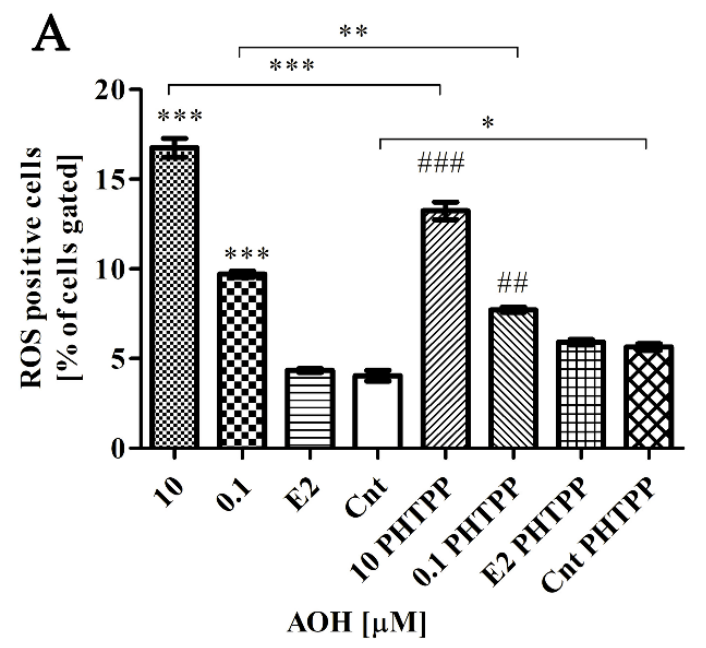

B

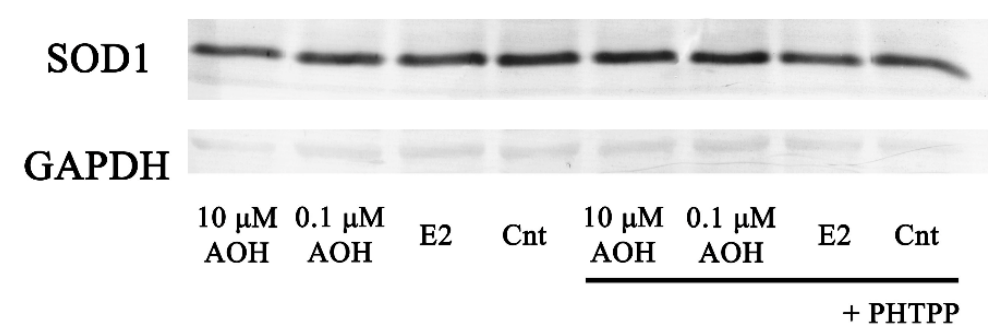

Figure 2. Blocking of ER $\beta$ decreases AOH- induced oxidative stress in PNT1A cells. (A) ROS positive cells counted with Muse ${ }^{\circledR}$ Cell Analyzer. (B) Representative results of Western blot analysis of SOD1 expression. All results are expressed as mean \pm SE. One-way ANOVA was used for statistical analysis. $p<0.05$ was considered as statistically significant, ${ }^{*} p<0.05$, ${ }^{* *} p<0.01,{ }^{* * *} p<0.001$, \#\# $p<0.01$, \#\#\# $p<0.001$ as compared to Cnt PHTPP. AOH—alternariol, PHTPP-ER $\beta$ inhibitor, Cnt—control. The experiments were run in 3 replications.

Table 1. The relative expression of SOD1 obtained in Western blot. Quantification of bands intensity was measured with Image J software. The results are expressed as a relative expression normalized to control value (1.000). SOD1—superoxide dismutase 1, Cnt—control, AOH-alternariol, E2—estradiol.

\begin{tabular}{ccccccccc}
\hline & $\begin{array}{c}\mathbf{1 0} \mu \mathrm{M} \\
\mathrm{AOH}\end{array}$ & $\begin{array}{c}\mathbf{0 . 1} \mu \mathrm{M} \\
\mathrm{AOH}\end{array}$ & E2 & Cnt & $\begin{array}{c}\mathbf{1 0} \mu \mathrm{M} \mathrm{AOH}+ \\
\text { PHTPP }\end{array}$ & $\begin{array}{c}\mathbf{0 . 1} \mu \mathrm{M} \text { AOH }+ \\
\text { PHTPP }\end{array}$ & $\begin{array}{c}\text { E2 }+ \\
\text { PHTPP }\end{array}$ & $\begin{array}{c}\mathrm{Cnt}+ \\
\text { PHTPP }\end{array}$ \\
\hline SOD1 & 1.652 & 1.288 & 1.029 & 1.000 & 0.870 & 0.935 & 1.159 & 1.224 \\
\hline
\end{tabular}

We also observed that induction of oxidative stress was associated with modulation of the expression of SOD1, HIF-1 $\alpha$ and RelA (Table 2). In case of all tested genes the changes observed after $\mathrm{AOH}$ treatment were not significant, however the significant changes in the expression of HIF-1 $\alpha\left({ }^{* *} p<0.01\right)$ and RelA were observed after addition of PHTPP to $\mathrm{AOH}$-treated cells as compared to $\mathrm{AOH}$ treatment alone $\left.{ }^{* * *} p<0.001\right)$. On the protein level we observed an almost $60 \%$ increase in SOD1 expression after treatment with higher dose of $\mathrm{AOH}$ and $30 \%$ increase in the case of lower $\mathrm{AOH}$ dose compared to control cells (Figure 2B). Addition of PHTPP reduced the expression to $87 \%$ for higher dose and $94 \%$ of untreated cells. The expression of SOD1 in cells treated only with PHTPP was, similar to the RT-qPCR results, slightly increased (22\%) compared to control cells. 
Table 2. The relative expression of genes obtained in RT-qPCR study. The results are expressed as mean value of at least three independent replications. One way ANOVA was used for statistical comparison. $p<0.05$ was considered as statistically significant, ${ }^{* *} p<0.01,{ }^{* * *} p<0.001$, as compared to $10 \mu \mathrm{M}$ AOH. SOD1-superoxide dismutase 1 , HIF- $1 \alpha-$ hypoxia inducible factor $1 \alpha$, RelA—nuclear factor NF-Kappa-B p65 subunit, Cnt—control, AOH—alternariol, E2—estradiol.

\begin{tabular}{cccccccccc}
\hline Gene & $\begin{array}{c}\mathbf{1 0} \boldsymbol{\mu M} \\
\mathbf{A O H}\end{array}$ & $\begin{array}{c}\mathbf{0 . 1} \boldsymbol{\mu M} \\
\mathbf{A O H}\end{array}$ & E2 & Cnt & $\begin{array}{c}\mathbf{1 0} \boldsymbol{\mu M} \text { AOH }+ \\
\text { PHTPP }\end{array}$ & $\begin{array}{c}\mathbf{0 . 1} \boldsymbol{\mu M} \text { AOH + } \\
\text { PHTPP }\end{array}$ & $\begin{array}{c}\text { E2 }+ \\
\text { PHTPP }\end{array}$ & $\begin{array}{c}\text { Cnt }+ \\
\text { PHTPP }\end{array}$ \\
\hline SOD1 & 1.97 & 2.45 & 2.25 & 2.37 & 2.04 & 2.98 & 2.51 & 2.58 \\
\hline HIF-1 $\alpha$ & 0.74 & 0.94 & 0.80 & 0.86 & $1.07^{* *}$ & 0.99 & 0.84 & 0.83 \\
\hline RelA & 13.91 & 21.08 & 16.61 & 18.08 & $27.61^{* * *}$ & 29.09 & 22.83 \\
\hline
\end{tabular}

\subsection{AOH Induces DNA Damage in PNT1A Cells}

Next, we evaluated if ER $\beta$ participates in AOH-induced DNA damage in cells. Firstly, it was observed that higher concentration of $\mathrm{AOH}$, as expected, induced DNA damage in PNT1A cells (Figure 3A). Addition of PHTPP, similarly to oxidative stress results, significantly decreased the induction of DNA damage as compared to $\mathrm{AOH}$ treatment alone $\left({ }^{*} p<0.01\right)$, but was not sufficient to completely prevent it (\#\# $p<0.01$ as compared to Cnt + PHTPP). The DNA damage was also visible in DNA staining as fragmented and not round-shaped nuclei of cells (Figure 3C). We also evaluated the expression of poly [ADP-ribose] polymerase 1(PARP1) both on mRNA and protein level, due to the fact that it acts as a first response to DNA damage in cells. We observed that a higher dose of $\mathrm{AOH}$ decreased expression of PARP1 (Figure 3B). In case of both doses of $\mathrm{AOH}$, blocking of $\mathrm{ER} \beta$ caused increase in the expression of PARP1, statistically significant for lower dose of $\mathrm{AOH}\left({ }^{*} p<0.05\right)$. The increase in the expression was also present in control cells treated only with PHTPP as compared to control $\left({ }^{*} p<0.05\right)$. On the protein level, decreased expression of cleaved PARP1 was found in cells treated with a higher dose of $\mathrm{AOH}$ as compared to non-treated cells (Table 3). Cells treated with PHTPP presented similar expression of cleaved PARP1 in all tested doses.

Table 3. The relative expression of cleaved- PARP1 obtained in Western blot. Quantification of bands intensity was measured with Image J software. The results are expressed as a relative expression normalized to control value (1.000). PARP1-Poly [ADP-ribose] polymerase 1, Cnt—control, $\mathrm{AOH}$-alternariol, E2—estradiol.

\begin{tabular}{ccccccccc}
\hline & $\begin{array}{c}\mathbf{1 0} \mu \mathrm{M} \\
\mathrm{AOH}\end{array}$ & $\begin{array}{c}\mathbf{0 . 1} \boldsymbol{\mu M} \\
\text { AOH }\end{array}$ & E2 & Cnt & $\begin{array}{c}\mathbf{1 0} \mu \mathrm{M} \mathrm{AOH}+ \\
\text { PHTPP }\end{array}$ & $\begin{array}{c}\mathbf{0 . 1} \mu \mathrm{M} \text { AOH }+ \\
\text { PHTPP }\end{array}$ & $\begin{array}{c}\text { E2 }+ \\
\text { PHTPP }\end{array}$ & $\begin{array}{c}\text { Cnt }+ \\
\text { PHTPP }\end{array}$ \\
\hline Cleaved-PARP1 & 0.616 & 0.732 & 0.625 & 1.000 & 0.767 & 0.868 & 0.847 & 0.846 \\
\hline
\end{tabular}

\subsection{AOH Induces Cell Cycle Arrest in G2/M Cell Cycle Phase}

The modulation of oxidative stress might be also associated with modulation of the progression of cell cycle. Our previous studies showed that mycotoxins modulate the progression of G2/M cell cycle phase [16,17]. Similarly to other estrogenic mycotoxin zearalenone, $\mathrm{AOH}$ in higher dose caused significant decrease in G1 cell cycle phase with simultaneous increase in $S$ and G2/M cell cycle phase indicating cell cycle arrest in G2/M cell cycle phase (Figure 4A,B). In case of G2/M cell cycle phase, the addition of PHTPP caused statistically significant decrease in the number of cells in G2/M cell cycle phase $\left.{ }^{* * *} p<0.05\right)$, however addition of PHTPP was not sufficient to counteract an increase in the number of PNT1A cells in G2/M phase. Similar effect was observed for control and control + PHTPP cells (** $p<0.05)$. The progression of G2/M cell cycle phase is regulated by cyclin B1 (CCNB1) and cyclin-dependent kinase 1 (CDC2). We evaluated the expression of CCNB1 and CDC2 and observed that $\mathrm{AOH}$ in the dose of $10 \mu \mathrm{M}$ significantly induces expression of both genes (*** $p<0.001$ ) as compared to control cells (Figure 4C). No significant increase was observed for lower dose of AOH. For both genes, the addition of PHTPP to a higher dose of AOH caused decreased expression as compared to $\mathrm{AOH}$ treatment alone $\left.{ }^{* *} p<0.01\right)$. Similar effect was observed for estrogenic control in the expression of CDC2 $\left({ }^{*} p<0.05\right)$. 
A

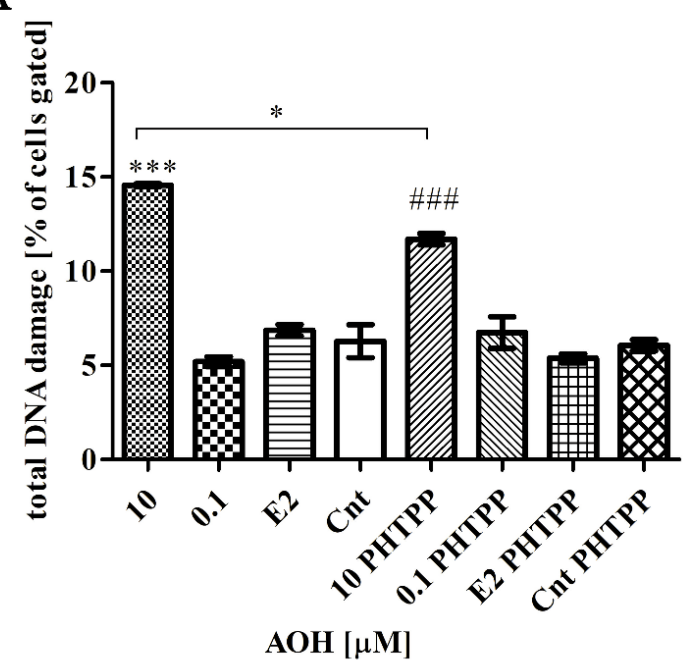

C

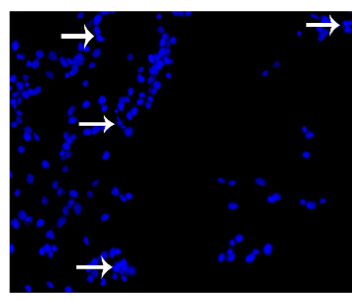

$10 \mu \mathrm{M} \mathrm{AOH}$

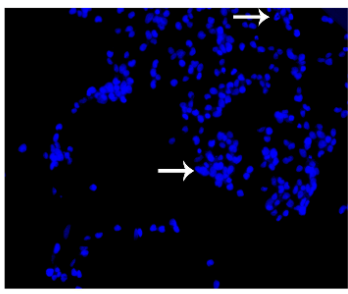

$10 \mu \mathrm{M}$ AOH + PHTPP

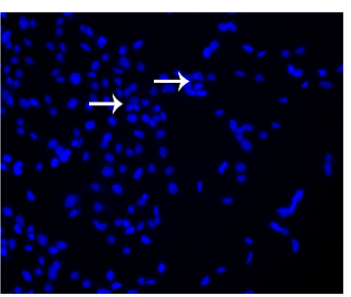

$0.1 \mu \mathrm{M} \mathrm{AOH}$

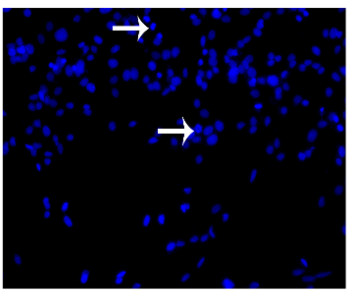

$0.1 \mu \mathrm{M} \mathrm{AOH}$ + PHTPP
B
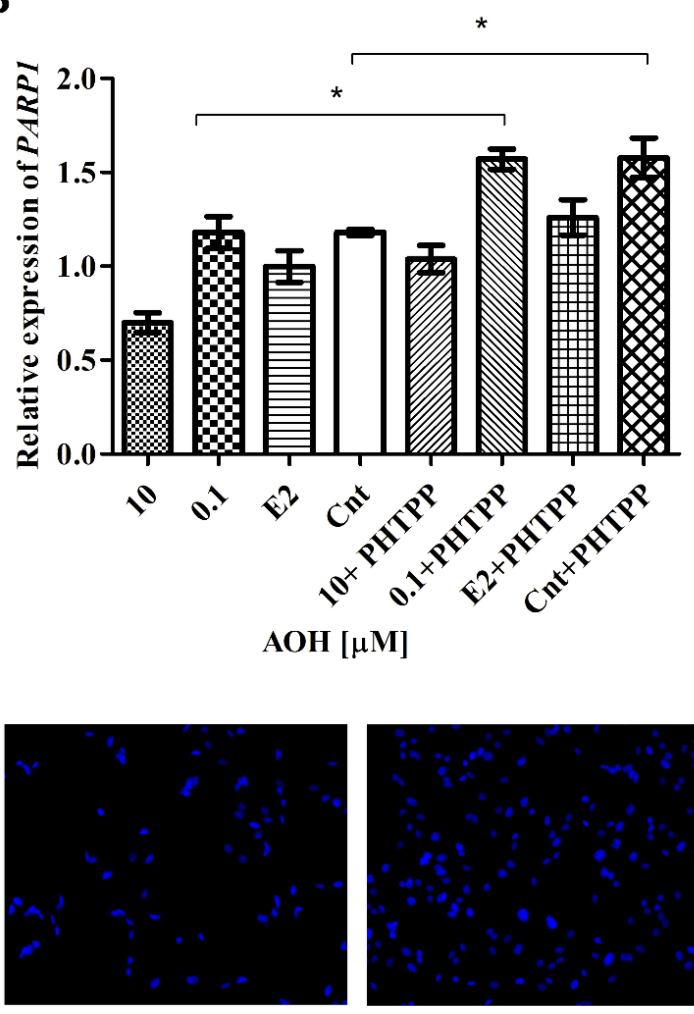

E2

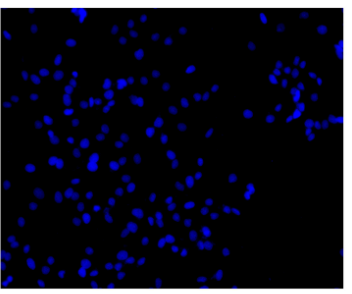

E2+ PHTPP

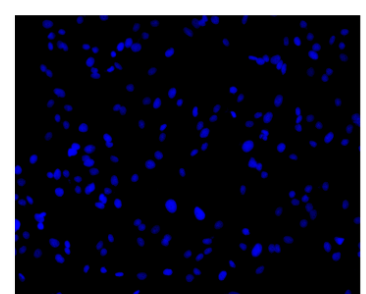

Cnt

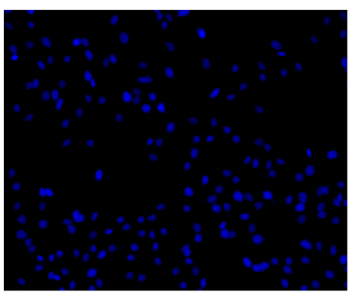

Cnt+ PHTPP

D

\section{PARP1}

GAPDH
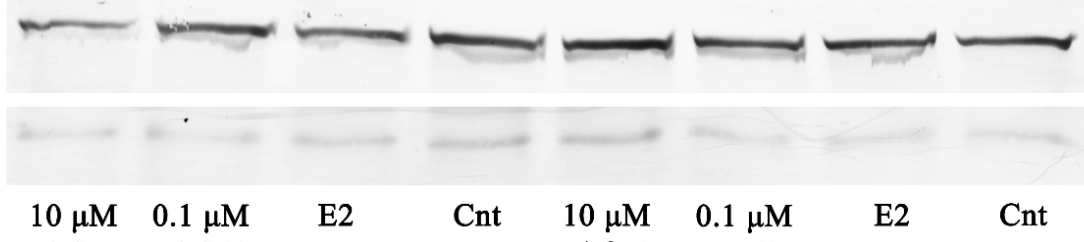

E2

Cnt

$\begin{array}{cc}10 \mu \mathrm{M} & 0.1 \mu \mathrm{M} \\ \mathrm{AOH} & \mathrm{AOH}\end{array}$

E2

Cnt

+ PHTPP

Figure 3. AOH induces DNA damage in PNT1A cells. (A) DNA damage was counted on Muse ${ }^{\circledR}$ Cell Analyzer and expressed as \% of cells gated. (B) Relative expression of PARP1 obtained in RT-qPCR. The results are expressed as mean \pm SE. (C) DAPI staining of the nuclei of cells. White arrows point at the cells with changed of fragmented nuclei. (D) Representative results of Western blot analysis of the expression of cleaved-PARP1 protein. One way ANOVA was used for statistical analysis. $p<0.05$ was considered as statistically significant. ${ }^{*} p<0.05,{ }^{* * *} p<0.001$ as compared to Cnt, \#\#\# $p<0.001$ as compared to Cnt PHTPP. AOH—alternariol, PHTPP—ER $\beta$ inhibitor, Cnt—control. The experiments were run in 3 replications. 

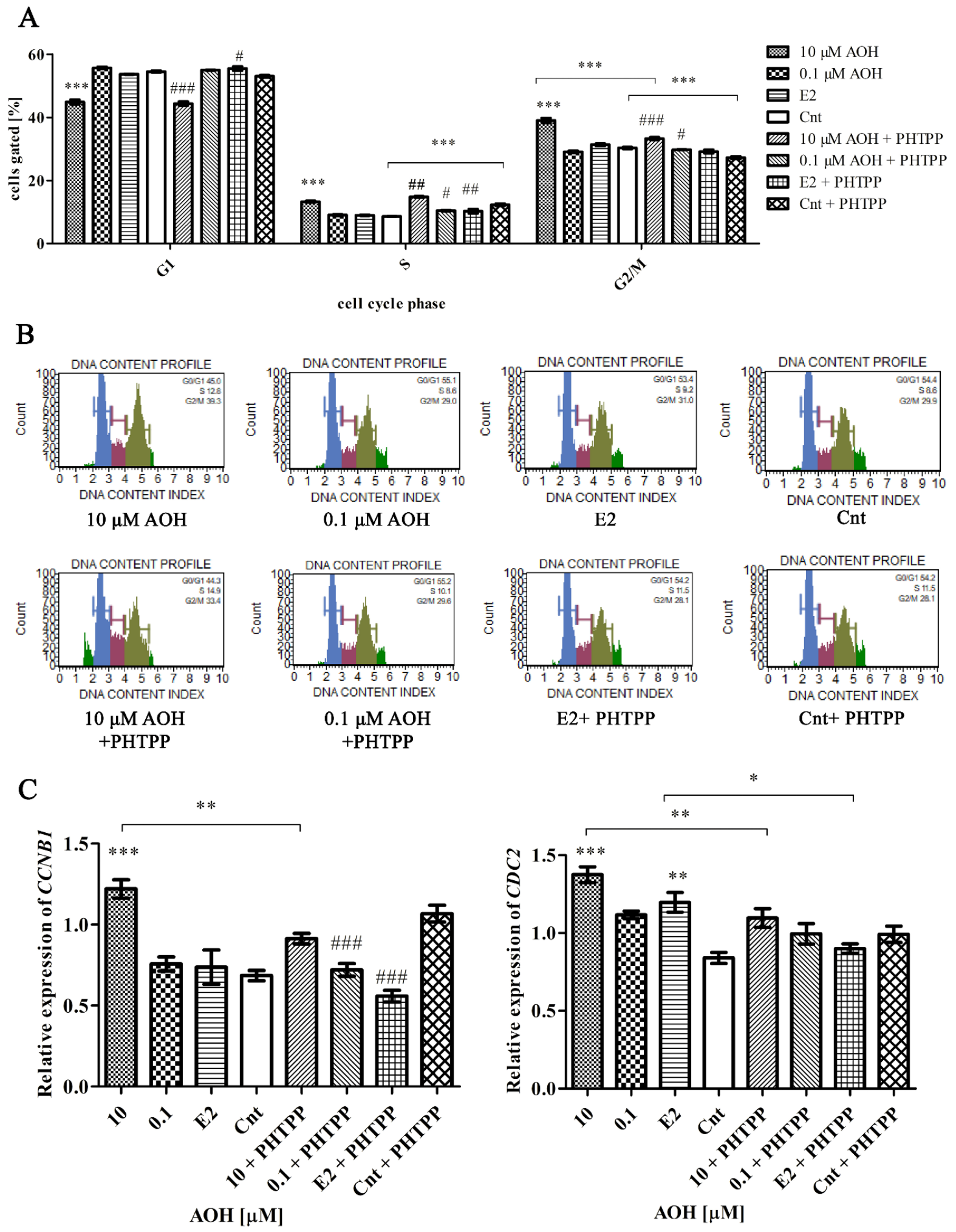

Figure 4. AOH induces cell cycle arrest in G2/M cell cycle phase. (A) The results of cell cycle analysis conducted with Muse ${ }^{\circledR}$ Cell Analyzer. The results are expressed as a mean \pm SE of the $\%$ of cells gated. (B) Representative results of the flow cytometry of cell cycle analysis. (C) RT-qPCR results of the relative expression of CCNB1 and CDC2. The results are expressed as mean \pm SE. One way ANOVA was used for statistical analysis. $p<0.05$ was considered as statistically

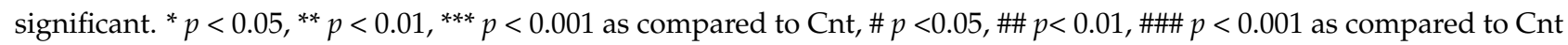
PHTPP. AOH—alternariol, PHTPP—ER $\beta$ inhibitor, Cnt—control, CCNB1—cyclin B1, CDC2—cyclin-dependent kinase 1. The experiments were run in 3 replications. 


\subsection{AOH Modulates Nrf2 Signaling Pathway}

The response to oxidative stress is mainly associated with activation of detoxifying enzymes and Nrf2 signaling pathway. Thus, we evaluated if $\mathrm{AOH}$-induced oxidative stress is associated with activation of Nrf2 signaling pathway (Figure 5). We observed that NRF2 and its responsive element $\mathrm{NAD}(\mathrm{P}) \mathrm{H}$ quinone dehydrogenase 1 (NQO1) was significantly decreased after exposure to $10 \mu \mathrm{M}$ AOH as compared to control $(* * *<0.001)$. In the case of other responsive element glutamate-cysteine ligase regulatory subunits (GCLM), a similar effect was observed but was not statistically significant. Interestingly, we did not observe any change in heme oxygenase 1 ( $H M O X)$, indicating that it does not participate in the $\mathrm{AOH}$-induced oxidative stress response. Although a slight increase in the expression of NRF2, NQO1, and GCLM was observed after addition of PHTPP, the changes were not significant.

A

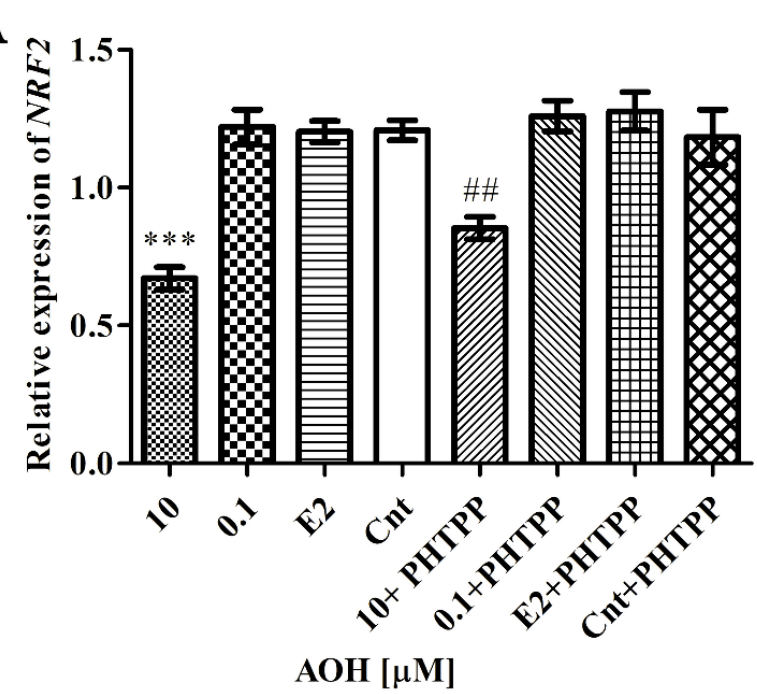

C

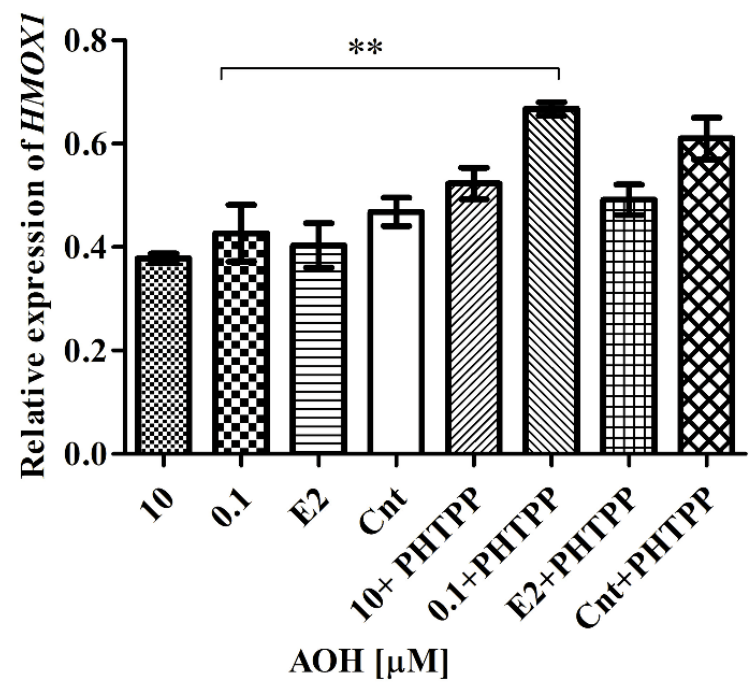

B

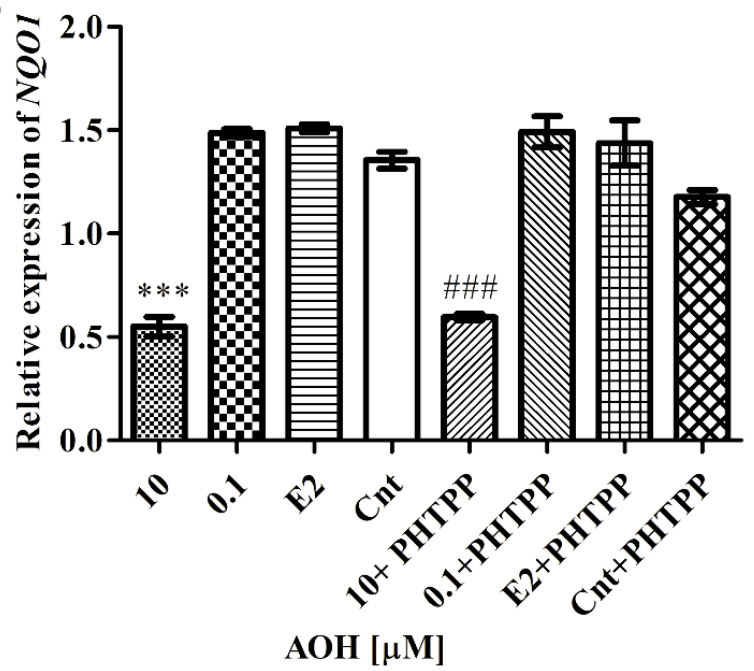

D

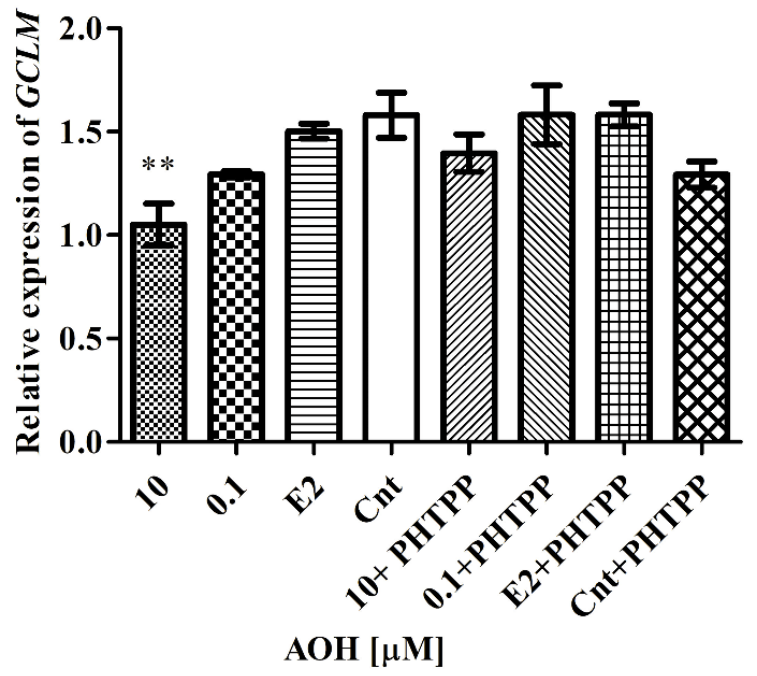

Figure 5. Relative expression of Nrf2 signaling pathway components. The relative expression of NRF2 (A), NQO1 (B), HMOX1 (C), and GCLM (D) obtained in RT-qPCR and expressed as mean \pm SE. H3F3A, RPLP0 and RPS17 were used as house-keeping genes. One- way ANOVA was used for statistical analysis. $p<0.05$ was considered as significant. ${ }^{* *} p<0.01$, *** $p<0.001$ as compared to control, \#\# $p<0.01$, \#\#\# $p<0.001$ as compared to Cnt + PHTPP. The experiment was run in 3 replications. AOH—alternariol, PHTPP—ER $\beta$ inhibitor, Cnt—control, Nrf2-nuclear factor erythroid 2-related factor 2, NQO1-NAD $(\mathrm{P}) \mathrm{H}$ dehydrogenase [quinone] 1, HMOX — heme oxygenase 1, GCLM—glutamate-cysteine ligase regulatory subunit, RPS17-Ribosomal protein S17, RPLP0—ribosomal protein P0, H3F3A-histone H3.3A. 


\subsection{AOH Modulates Motility of Prostate Epithelial Cells}

The motility of cells is crucial to maintain a proper functioning of cells. Thus, in the next step we evaluated migration of cells after treatment with $\mathrm{AOH}$ (Figure 6A). In both tested doses of $\mathrm{AOH}$ we observed a significant $\left({ }^{* *} p<0.01\right)$ decrease in cell migration as compared to control cells. The blocking of ER $\beta$ (+PHTPP) lowered the effect of AOH in both tested doses; however, it was significant only for the lower dose of $\mathrm{AOH}(* * p<0.01)$. The lower migration of cells observed after $\mathrm{AOH}$ treatment might be associated with decreased activity of metalloproteinases (MMP-2 and MMP-9), detected during zymography assay (Table 4, Figure 6B). The higher decrease in MMP-2 activity was observed for $0.1 \mu \mathrm{M} \mathrm{AOH}$ and addition of PHTPP increased that. No such effect was observed for $10 \mu \mathrm{M} \mathrm{AOH}$. In case of MMP-9 activity AOH decreased it slightly in both doses and similarly to MMP-2 activity, addition of PHTPP increased it, although the effect for lower dose of $\mathrm{AOH}$ was more detectable.

\section{A}

อ $\left.\begin{array}{r}10 \\ 5 \\ 0 \\ -5 \\ -10\end{array}\right]$
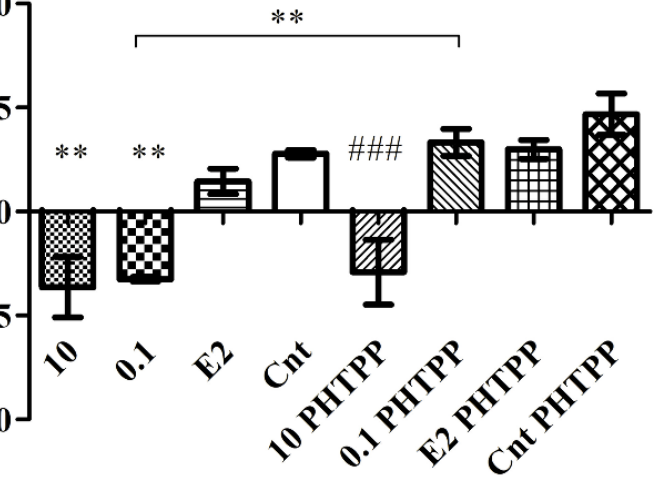

$\mathbf{A O H}[\mu \mathrm{M}]$
B

MMP-9

MMP-2

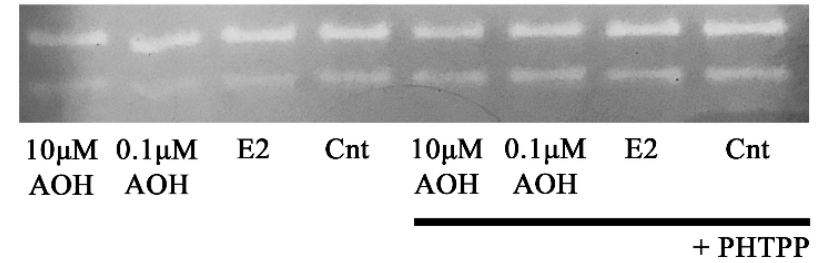

Figure 6. AOH decreases migration of PNT1A cells. (A) Migration of cells was evaluated with scratch assay. (B) Zymography was used to evaluate the activity of MMP-9 and MMP-2. The results are expressed as mean \pm SE. One- way ANOVA was used for statistical analysis. $p<0.05$ was considered as statistically significant. ${ }^{* *} p<0.01$ as compared to Cnt, \#\#\# $p<0.001$ as compared to Cnt PHTPP. AOH—alternariol, PHTPP—ER $\beta$ inhibitor, Cnt—control. The experiments were run in 3 replications.

Table 4. The activity of MMP-2 and MMP-9 obtained during zymography assay. The results are expressed as mean \% of the control, of three replicates. One way ANOVA was used for statistical comparison. $p<0.05$ was considered as statistically significant. MMP-2 metalloproteinase 2, MMP-9—metalloproteinase 9, AOH—alternariol, Cnt—control, E2—estradiol.

\begin{tabular}{ccccccccc}
\hline Gene & $\begin{array}{c}\mathbf{1 0} \boldsymbol{\mu M} \\
\text { AOH }\end{array}$ & $\begin{array}{c}\mathbf{0 . 1} \boldsymbol{\mu M} \\
\text { AOH }\end{array}$ & E2 & Cnt & $\begin{array}{c}\mathbf{1 0} \mu \mathrm{M} \mathrm{AOH}+ \\
\text { PHTPP }\end{array}$ & $\begin{array}{c}\mathbf{0 . 1} \boldsymbol{\mu M ~ A O H ~ + ~} \\
\text { PHTPP }\end{array}$ & $\begin{array}{c}\text { E2 }+ \\
\text { PHTPP }\end{array}$ & $\begin{array}{c}\text { Cnt }+ \\
\text { PHTPP }\end{array}$ \\
\hline$M M P-2$ & 81.86 & 69.76 & 86.22 & 100.0 & 79.47 & 84.82 & 93.27 & 91.63 \\
\hline$M M P-9$ & 91.16 & 94.22 & 100.9 & 100.0 & 98.74 & 110.6 & 98.44 & 96.52 \\
\hline
\end{tabular}

\subsection{AOH Affects Inflammatory Response in PNT1A Cells}

It was previously suggested that $\mathrm{AOH}$ affects the inflammatory response in cells [18]. We observed that $10 \mu \mathrm{M}$ AOH significantly affect expression of interleukin 6 (IL-6), both on mRNA and protein level. The expression of IL6 was significantly increased after $10 \mu \mathrm{M} \mathrm{AOH}(* p<0.05)$, a contradictory yet not significant effect was observed for $0.1 \mu \mathrm{M}$ $\mathrm{AOH}$. Addition of PHTPP reduced abovementioned increase in IL6 expression (Figure 7A). The protein expression of IL6 evaluated with ELISA showed a remarkable increase in its expression after treatment with the higher dose of $\mathrm{AOH}\left({ }^{* * *} p<0.001\right)$ as compared to 
control (Figure 7C). Blocking of ER $\beta$ with PHTPP decreased significantly expression of IL6 $\left({ }^{*} p<0.05\right)$, but still the expression was elevated as compared to Cnt + PHTPP treatment (\#\#\# $p<0.001$ ). A contradictory effect was observed in the expression of interleukin $1 \beta(I L-1 \beta)$, where treatment with $10 \mu \mathrm{M} \mathrm{AOH}$ significantly $(* * * p<0.001)$ decreased its expression and blockage of ER $\beta$ did not change that effect (\#\# $p<0.01$ ) as compared to Cnt + PHTPP (Figure 7B). The expression of IL-1 $\beta$ was not detectable at the protein level (data not showed).

A

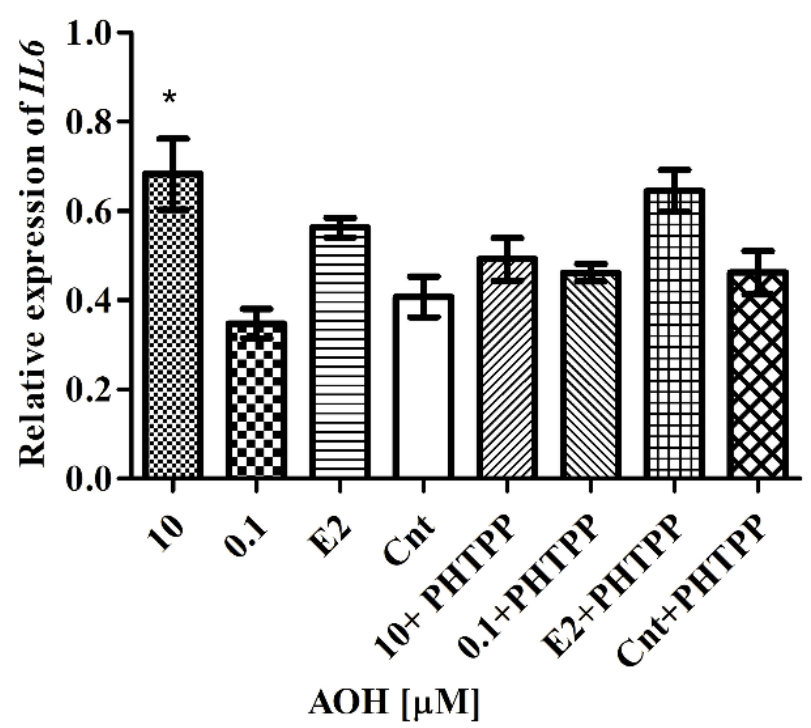

C

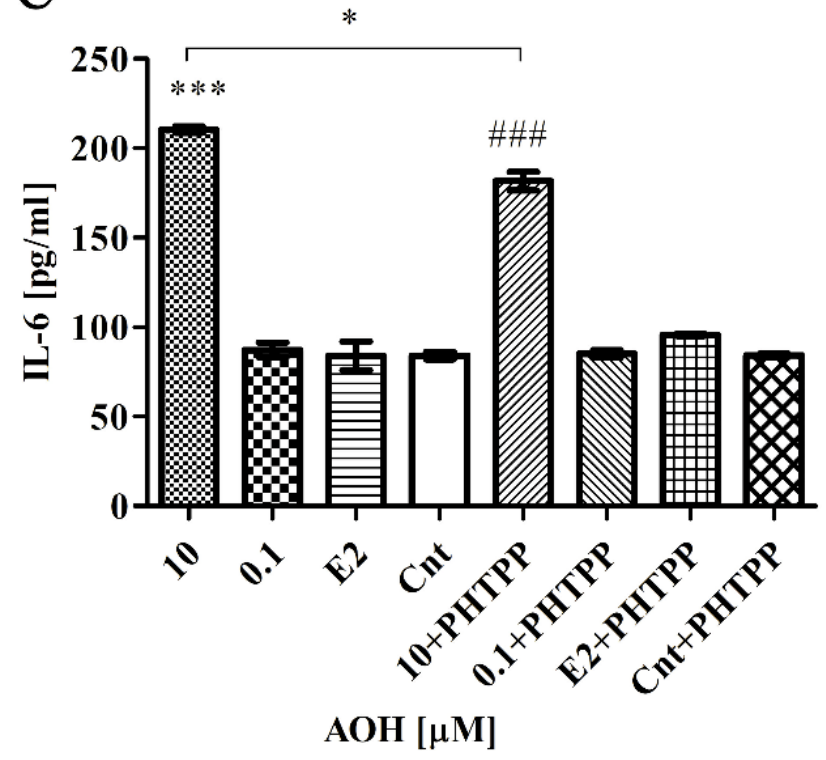

B

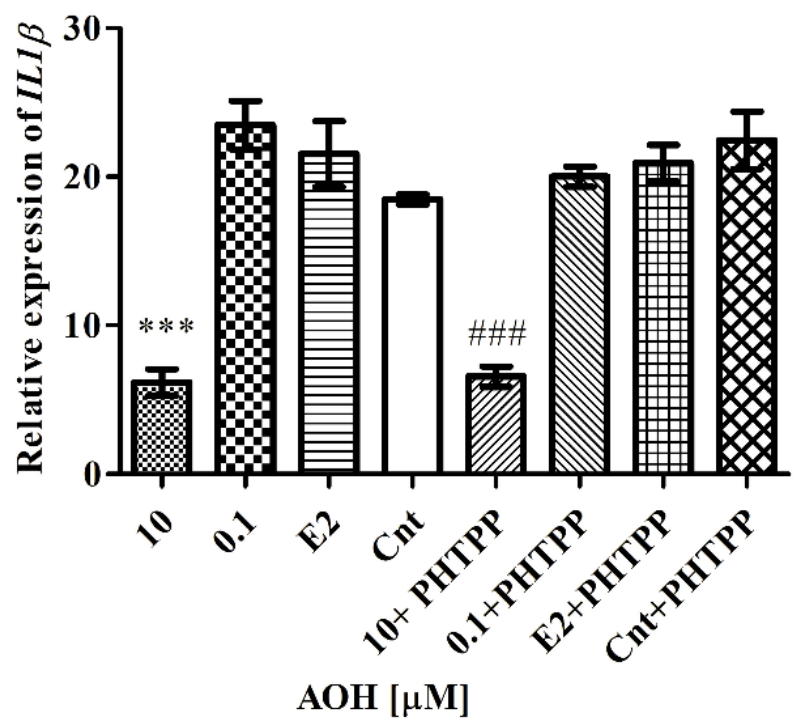

Figure 7. The relative expression of $I L 6$ and $I L-1 \beta$. (A,B) The relative expression of $I L 6$ and $I L-1 \beta$ obtained in RT-qPCR and expressed as mean \pm SE. H3F3A, RPLP0 and RPS17 were used as house-keeping genes. One way ANOVA was used for statistical analysis. $p<0.05$ was considered as significant. (C) The relative expression of IL6 obtained in ELISA test. The results are expressed as mean $\pm \mathrm{SE}$ of two replications. ${ }^{*} p<0.05,{ }^{* * *} p<0.001$ as compared to control, \#\#\# $p<0.001$ as compared to Cnt + PHTPP. AOH—alternariol, PHTPP—ER $\beta$ inhibitor, Cnt-control, IL6-interleukin 6, IL-1 $\beta$-interleukin 1 subunit $\beta$, RPS17-Ribosomal protein S17, RPLP0-ribosomal protein P0, H3F3A-histone H3.3A. 


\section{Discussion}

Toxins produced by Alternaria, including $\mathrm{AOH}$ are so-called "emerging mycotoxins" a term defining the need for more evidence of their occurrence and toxicological properties. Although the human dietary exposure to $\mathrm{AOH}$ seems to be low, it exceeds the threshold of toxicological concern (TTC) [19] and there is still insufficient research concerning its mechanism and effects on human health [20]. This study evaluated for the first time the effect of $\mathrm{AOH}$ on the induction of oxidative stress in prostate normal epithelial cells via modulation of ER $\beta$. The results presented here show that $\mathrm{AOH}$ induced oxidative stress in PNT1A cells is associated with DNA damage (Figure 3), cell cycle arrest in G2/M cell cycle phase (Figure 4 ) and that effect is partially caused by activation of ER $\beta$ confirming a previous statement that $\mathrm{AOH}$ possesses estrogenic effect in cells [9]. The doses used in the experiment were chosen on the basis of viability results and are consistent with the doses tested in other studies [10,15].

Although the observed cytotoxic effect of AOH in PNT1A cells (Figure 1) was only partially caused by activation of $E R \beta$, it confirms the previous observation that $\mathrm{AOH}$ is more likely to affect $\mathrm{ER} \beta$ then $\mathrm{ER} \alpha$ [20]. The role of $\mathrm{ER} \beta$ in prostate tissue is twofold—on one hand it is reported to act as tumor suppressor, lack of which results in carcinogenesis in mice [21], however on the other hand its expression is increasing in high tumor grades, indicating that ER $\beta$ suppresses proliferation of prostate cells, but stimulates its differentiation [22]. In this study, blocking of ER $\beta$ was not sufficient to completely reduce $\mathrm{AOH}-$ induced oxidative stress and DNA damage observed in PNT1A cells (Figures 2 and 3), indicating that $\mathrm{AOH}$-induced oxidative stress is mostly associated with its genotoxicity. The modulatory effect of estrogens in ROS induction in prostate cells was observed previously and seemed to be dependent on the ER $\alpha / E R \beta$ ratio in cells [23]. AOH was previously reported to induce oxidative stress in human colon carcinoma cells in doses higher than $1 \mu \mathrm{M}$ [24], whereas in human colon adenocarcinoma cells Caco-2 AOH induced oxidative stress in doses higher than $15 \mu \mathrm{M}$ [25]. In our study, the concentration of $10 \mu \mathrm{M}$ of $\mathrm{AOH}$ was sufficient to induce ROS generation in PNT1A cells (Figure 2). However, the induction of oxidative stress was still associated with activation of detoxifying enzymes (SOD1) as well as Nrf2 signaling pathway. $\mathrm{AOH}$ was reported to increase the translocation of Nrf2 to nuclei in HT29 cells [26]. In this study we observed that AOH significantly decreased expression of NRF2 and modulated the expression of its responsive genes. A similar Nrf2 signaling pathway modulation effect of $\mathrm{AOH}$ was previously observed by us in normal mammary gland epithelial cells; however, in that study NRF2 expression was not changed [27].

The toxic effect of $\mathrm{AOH}$ was previously mostly associated with its ability to act as topoisomerase inhibitor [6]. In this study we also observed that $\mathrm{AOH}$ induces DNA damage and cell cycle arrest in G2/M cell cycle phase (Figures 3 and 4) was associated with modulation of the decreased expression of PARP1 and increased expression of CCNB1 and $C D C 2$ main regulators of G2 cell cycle progression [28]. PARP1 modulation was reported in the study concerning the mycotoxin aflatoxin B1, in response to DNA damage [29], similarly to our study. The modulation of cell cycle progression was also associated with DNA damaging effect of AOH in RAW 264.7 cells [5], where, similarly to our study, G2/M cell cycle arrest was observed.

$\mathrm{ER} \beta$ was previously reported to participate in chronic inflammation in prostate via the NFKB HIF-1 $\alpha$ signaling pathway [30]. In this study, as well as the induction of oxidative stress, we observed that $\mathrm{AOH}$ decreased the expression of HIF1 $\alpha$ and that effect was reversed by locking ER $\beta$ with its selective inhibitor PHTPP. We also observed that $A O H$ affects RelA expression. This result is in line with previous one indicating that $\mathrm{AOH}$ affects NFKB signaling pathway [18].

Extracellular matrix (ECM) molecules are considered as regulators of cells growth [31]. We observed that AOH significantly affected migration of PNT1A cells and that effect was associated with modulation of activity of MMP-2 and MMP-9 (Figure 6). Modulation of these components of ECM was previously reported as a factor in carcinogenesis and metas- 
tases, as well as age-related diseases [32]. The dual role of ER $\beta$ in prostate carcinogenesis was mentioned before: it seems that during early stages of prostate carcinogenesis ER $\beta$ acts as a tumor suppressor, but in more advanced disease it switches to a metastatic promoting role [33]. In this study we observed that lower concentration of $\mathrm{AOH}(0.1 \mu \mathrm{M})$ decreased migration of normal prostate epithelial cells, whereas co-incubation with an ER $\beta$ blocker caused a contradictory effect (Figure 6). The ECM role is also associated with inflammatory states [32]. IL-1 $\beta$ was associated with inflammation-induced invasion of prostate cancer cells [34]. AOH was previously reported to modulate the immune response in different cell lines $[18,35]$. IL-1 $\beta$ stimulated Caco- 2 cells treated with AOH showed reduced IL-1 $\beta$ and IL6 expression [36]; decreased expression of IL6 and suppressed LPS-induced NFKB activation in THP-1 derived macrophages [18], whereas in RAW 264.7 mouse macrophages $\mathrm{AOH}$ increased IL6 expression [6]. The results of this study also showed that AOH modulates the expression of IL6 (increase) and $I L-1 \beta$ (decrease) in normal prostate epithelial cells (Figure 7). IL6 was reported to modulate progression, differentiation, survival, and angiogenesis of PCa [36], moreover it was shown to mediate AR activation in benign and malignant prostate models [37]. Although ER $\beta$ is reported to suppress inflammation in prostate cells [38], in our study, blocking of ER $\beta$ decreased the expression of IL6, but still it seems that the immunomodulatory effect of $\mathrm{AOH}$ was sustained and visible in the increased IL6 and decreased Il-1 $\beta$ expression. Previous research showed that AOH might act as immunomodulatory and xenoestrogenic agent. Bansal et al. observed that $\mathrm{AOH}$-induced toxicity in derma cells is associated with inflammatory response to topical administration of $\mathrm{AOH}$ manifested by increased production of Cox-2 and $\mathrm{PGE}_{2}$ [39]. Another pro-inflammatory effect of AOH was reported in RAW264.7 mouse macrophages [6]. On the other hand, Kollarova et al. observed that AOH decreases LPS-induced inflammation in macrophages and proposed the molecular mechanism associated with modulation of NFKB signaling pathway [18]. The mechanism of AOH-induced modulation of inflammatory response was evaluated by Favero et al. who suggested that structural similarity of $\mathrm{AOH}$ to cholesterol might provide a clue for understanding the biological effect triggered by $\mathrm{AOH}$. Moreover, the authors suggested that $\mathrm{AOH}$ is more likely to affect signal transduction in cells, rather than its generation [40]. This fact seems to correspond to the results obtained by us, also to the estrogenic effect of $\mathrm{AOH}$. This observations are also in line with previous one based on in silico and in vitro research, where metabolites of $\mathrm{AOH}$ triggered an estrogenic effect without direct binding to ERs in cells [41].

Taken together, $\mathrm{AOH}$ seems to act as immunomodulatory and estrogenic agent in cells and its biological effect might be dependent on the presence of other estrogenic stimuli, immunomodulatory agents as well as its metabolic modification in cells.

\section{Conclusions}

To the best of our knowledge, this is the first study which reports that AOH induces oxidative stress in normal prostate epithelial cells and that the effect is partially dependent on ER $\beta$ activation. The results of this study also confirm a previous reports indicating that $\mathrm{AOH}$ induces DNA damage, cell cycle arrest in G2/M cell cycle phase and acts as immunomodulatory agent affecting expression of IL6 and IL-1 $\beta$. Due to the fact that hormonal imbalance and inflammation are crucial in both prostate benign and metastatic diseases, further research is needed to elucidate the role of $\mathrm{AOH}$ in prostate cells.

\section{Materials and Methods}

\subsection{Cell Culture}

PNT1A, normal human prostatic cell line, was supplied by the European Collection of Authenticated Cell Cultures (ECACC, Sigma-Aldrich, Saint Louis, MO, USA). Cells were cultured in an incubator under standard conditions $\left(37^{\circ} \mathrm{C}, 5 \% \mathrm{CO}_{2}, 95 \%\right.$ humidity). RPMI-1640 with additives (10\% FBS, 1\% of sodium pyruvate, L-glutamine, HEPES and antibiotics) was used as a culture medium. For assays, an experimental medium without phenol red, antibiotics and FBS was used. 


\subsection{Reagents \& Treatments}

$\mathrm{AOH}$ used in the study was derived from Sigma-Aldrich ${ }^{\circledR}$. 2-Phenyl-3-(4-hydroxyphenyl)5,7-bis (trifluoromethyl)-pyrazolo stock solution [1,5- $\alpha$ ]pyrimidine (PHTPP) was derived from Santa Cruz Biotechnology (1 mM, Santa Cruz Biotechnology, Dallas, TX, USA). Both compounds were dissolved in DMSO and the final concentration was obtained by dissolution in experimental medium directly before treatment. The concentration of DMSO in final experimental medium was negligibly low $(<0.01 \%)$ and did not affect the behavior of cells in all experiments. Based on viability test results, two doses of $\mathrm{AOH}$ were used $(10 \mu \mathrm{M}$ and $0.1 \mu \mathrm{M})$. Estradiol (E2) was used as positive control. As a control (Cnt), cells treated with the clear experimental medium were used. Combination of treatment: $10 \mu \mathrm{M}$ AOH, $10 \mu \mathrm{M}$ AOH + PHTPP, $0.1 \mu \mathrm{M} \mathrm{AOH}, 0.1 \mu \mathrm{M}$ AOH + PHTPP, E2, E2 + PHTPP, and Cnt.

\subsection{Cell Viability and Morphology}

The viability of cells was evaluated by AlamarBlue ${ }^{\circledR}$ assay (Thermo Fisher Scientific Inc/Life Technologies, Saint Louis, MO, USA). Cells were seeded on 96-well plates $(2 \times 108$ per well $)$ and after one day, were treated with the experimental medium containing $\mathrm{AOH}$ in a concentration range of $0.001-100 \mu \mathrm{M}$ for 24 and $48 \mathrm{~h}$. After $20 \mathrm{~h}$ and after $44 \mathrm{~h}$, respectively, $10 \mu \mathrm{L}$ of AlamarBlue ${ }^{\circledR}$ reagent was added and then plates were incubated in standard conditions for the next $4 \mathrm{~h}$. Absorbance was measured at $570 \mathrm{~nm}$ and $600 \mathrm{~nm}$ in EL808IU BioTek microplate reader (BioTek Instruments, Inc., Winooski, VT, USA). Cell viability was expressed as percentage of $C$ nt cells. The cell viability assay was carried out in 6 replications.

\subsection{Oxidative Stress, DNA Damage and Cell Cycle Distribution}

All these flow cytometry assays were conducted with Muse ${ }^{\circledR}$ Cell Analyzer in accordance with manufactuer's recommendations (Luminex ${ }^{\circledR}$, Austin, TX, USA). Cells were seeded on 6-well plates (ROS, Cell cycle) and 12-well plates (DNA damage) and then cultured in standard conditions until they reach $90 \%$ confluence. For oxidative stress the Muse ${ }^{\circledR}$ Oxidative Stress Kit was used, for DNA damage Muse ${ }^{\circledR}$ Multi-Color DNA Damage Kit and for cell cycle distribution Muse ${ }^{\circledR}$ Cell Cycle Assay Kit. The experiments were conducted in triplicate.

\subsection{Enzyme-Linked Immunosorbent Assay (ELISA)}

Enzyme-linked Immunosorbent Assays (ELISA) were conducted for IL-6 and IL-1 $\beta$. The cells were seeded on 6-well plates and then treated with experimental medium as described above. After $24 \mathrm{~h}$, the cells and experimental medium from the wells were harvested and frozen at $-80^{\circ} \mathrm{C}$. Finally, the procedure was conducted according to the manufacturer's instructions. The experiment was conducted in duplicate.

\subsection{Scratch Assay}

Wound scratch assay was performed to assess the ability of normal prostate cells to migrate after treatment with AOH. PNT1A cells were seeded on 6-well plates and allowed to reach $80-90 \%$ confluence. Then, cells were scratched in a cross shape with $200 \mu \mathrm{L}$ sterile pipette tip, rinsed with DPBS $(1 \times)$ and treated with previously prepared experimental medium. Cells were photographed immediately after addition of experimental medium $(0 \mathrm{~h})$ and after $24 \mathrm{~h}$ with Olympus DP20 camera (Olympus, magnitude $40 \times$ ). Measurements of the difference between the wound area in $0 \mathrm{~h}$ and $24 \mathrm{~h}$ were used to determine migration. The wound area was measured in ImageJ software (https://imagej.nih.gov/ij/). The percentage of wound healing was calculated as shown below. The experiment was run in 3 replications.

$$
x=(\text { wound area }(24 h)) /(\text { wound area }(0 h))
$$

The percentage of wound closure $=(1-\mathrm{x}) \times 100 \%$ 


\subsection{Gelatin Zymography}

Gelatin zymography was performed to check whether the migration change after treatment with $\mathrm{AOH}$ was associated with activity of metalloproteinases (MMP-2 and MMP9). For this purpose, cells were seeded on 6-well plates and allowed to reach $80-90 \%$ confluence. Next, cells were treated with $\mathrm{AOH}$. Then, culture media were harvested and the concentration of the protein was determined using QubitR Protein Assay Kit (ThermoFisher Scientific, Inc, Waltham, MA, USA) according to the manufacturer's instructions. $4.75 \mu \mathrm{g} / \mu \mathrm{L}$ of protein was used for the assay. Samples were electrophoresed ( $120 \mathrm{~V}$, on ice) on $4 \%$ gelatin zymography gels, which were then incubated twice (30 $\mathrm{min}$ ) in $2.5 \%$ Triton X-100 (Sigma-Aldrich, Saint Louis, MO, USA). The gels were then incubated in developing buffer $\left(48 \mathrm{~h}, 37^{\circ} \mathrm{C}\right)$. After the incubation time, the gels were stained with Coomassie brilliant blue (Sigma-Aldrich, Saint Louis, MO, USA), decolorized with decolorizing buffer (3(methanol):1(acetic acid):6(distilled water)) and preserved in glycine solution. The gels were photographed and ImageJ program/) was used to calculate the intensity of the bands. The experiment was carried out in 3 replications.

\subsection{Real Time Quantitative Polymerase Chain Reaction (RT-qPCR)}

Cells were seeded on Petri dishes $(60 \mathrm{~mm})$ and incubated in standard conditions until $90 \%$ confluence was achieved. Then, cells were treated with experimental medium as described in Section 5.2. After $24 \mathrm{~h}$, total RNA was isolated using TRIzol reagent, according to the manufacturer's instruction. BioDrop DUO was used to determine RNA purity and concentration (Biodrop, Cambridge, UK). $5 \mu \mathrm{g}$ of RNA from each sample was used to synthesize cDNA by using ImProm RT-IITM reverse transcriptase (Promega, Madison, WI, USA). LightCycler 96 (Roche, Basel, Switzerland) was used to perform the RT-qPCR with $2 \mu \mathrm{L}$ of cDNA. Primer-BLAST was used to design primers. To calibrate reaction, Human Reference RNA (Stratagene, San Diego, CA, USA) was used. Ribosomal protein S17 (RPS17), ribosomal protein P0 (RPLP0), and histone H3.3A (H3F3A) were used as a reference genes. Sequences of primers used in the study are presented in Table 5. Specificity of received product was confirmed during analysis of melting curves for each reactions. The $\Delta \Delta \mathrm{Ct}$ method was used to analyze the obtained data. The experiment was performed in duplicate with three independent replications.

\subsection{Western Blot}

Cells were seeded on Petri dishes $(100 \mathrm{~mm}$ ) and cultured to reach $90 \%$ confluence. Then, they were treated with experimental medium for $24 \mathrm{~h}$. The protein isolation and western blots were conducted in accordance with previous study [16]. Primary antibodies used in the study were: anti-SOD1 (1:1000, Cell Signaling Technology, Leiden, WZ, The Netherlands, \#71G8), anti-cleaved PARP1 (1:1000, Cell Signaling Technology, Leiden, WZ, The Netherlands, \#D64E10), anti-GAPDH (1:2000, SantaCruz Biotechnology, Inc., Dallas, TX, USA, sc-59540). Novex ${ }^{\circledR}$ AP Chromogenic Substrate (Thermo Fisher Scientific Inc, Waltham, MA, USA) was used to visualize bands. Quantification of bands intensity was measured with Image J software. The results are expressed as a relative expression normalized to control value (1.000).

\subsection{Statistical Analysis}

Data were analyzed in GraphPad Prism program (GraphPad Software version 5, La Jolla, CA, USA). Statistical significance was determined with One-Way ANOVA and post-hoc Bonferroni test. A $p$ value lower than 0.05 indicates statistically significant results. 
Table 5. Sequences of primers used in RTqPCR.

\begin{tabular}{|c|c|c|}
\hline Gene & Sequence $\left(5^{\prime}-3^{\prime}\right)$ & Product Size $[b p]$ \\
\hline \multirow{2}{*}{$C D C 2$} & For TTTTCAGAGCTTTGGGCACT & \multirow[b]{2}{*}{100} \\
\hline & Rev AGGCTTCCTGGTTTCCATTT & \\
\hline \multirow{2}{*}{ CCNB1 } & For ACCTATGCTGGTGCCAGTG & \multirow{2}{*}{128} \\
\hline & Rev GGCTTGGAGAGCAGTA & \\
\hline \multirow{2}{*}{ GCLM } & For TGTGCAACTCCAAGGACTGA & \multirow[b]{2}{*}{247} \\
\hline & Rev ACAGCGAGGAGCTTCATGAT & \\
\hline \multirow{2}{*}{$H I F-1 \alpha$} & For TTACTCATCCATGTGACCATGA & \multirow{2}{*}{140} \\
\hline & Rev AGTTCTTCCTCGGCTAGTTAG & \\
\hline \multirow{2}{*}{ HMOX1 } & For CAGCTCCTGCAACTCCTCAAA & \multirow[b]{2}{*}{165} \\
\hline & Rev TTCTТСАССТТССССАACATTG & \\
\hline \multirow{2}{*}{ H3F3A } & For AGGACTTTAAAAGATCTGCGCTTCCAGAG & \multirow{2}{*}{74} \\
\hline & Rev ACCAGATAGGCCTCACTTGCCTCCTGC & \\
\hline \multirow{2}{*}{$I L-1 \beta$} & For GGCAATGAGGATGACTTGTT & \multirow{2}{*}{127} \\
\hline & Rev TGCTGTAGTGGTGGTCGGA & \\
\hline \multirow{2}{*}{ IL6 } & For GGATGCTTCCAATCTGGATTCA & \multirow{2}{*}{126} \\
\hline & Rev TCTGGCTTGTTCCTCACTACT & \\
\hline \multirow{2}{*}{ NQO1 } & For CCAGGATTTGAATTCGGGCG & \multirow{2}{*}{212} \\
\hline & Rev AGGACCCTTCCGGAGTAAGA & \\
\hline \multirow{2}{*}{ NRF2 } & For GTCACATCGAGAGCCCAGTC & \multirow[b]{2}{*}{193} \\
\hline & Rev ACCATGGTAGTCTCAACCAGC & \\
\hline \multirow{2}{*}{ PARP1 } & For TCTTCAAGAGCGATGCCTATT & \multirow{2}{*}{129} \\
\hline & Rev TGAGGTAAGAGATTTCTCGGAA & \\
\hline \multirow{2}{*}{ RelA } & For GCACAGATACCACCAAGACC & \multirow{2}{*}{157} \\
\hline & Rev TCAGCCTCATAGAAGCCATC & \\
\hline \multirow{2}{*}{$R P L P 0$} & For ACGGATTACACCTTCCCACTTGCTAAAAGGTC & \multirow{2}{*}{69} \\
\hline & Rev AGCCACAAAGGCAGATGGATCAGCCAAG & \\
\hline \multirow{2}{*}{ RPS17 } & For AAGCGCGTGTGCGAGGAGATCG & \multirow{2}{*}{87} \\
\hline & Rev TCGCTTCATCAGATGCGTGACATAACCTG & \\
\hline \multirow{2}{*}{ SOD1 } & For GCGTGGCCTAGCGAGTTAT & \multirow{2}{*}{114} \\
\hline & Rev. ACACCTTCACTGGTCCATTACT & \\
\hline
\end{tabular}

Author Contributions: Conceptualization, K.K. and A.W.P.-C.; investigation, K.K., M.J.K., K.A.U., D.E.H.-G. and K.D.; writing-original draft preparation, K.K. and M.J.K.; funding acquisition, A.W.P.C. All authors have read and agreed to the published version of the manuscript.

Funding: Medical University of Lodz grant no 503/0-078-03/503-01-001-19-00 and 503/0-078-03/50399-001.

Institutional Review Board Statement: Not applicable.

Informed Consent Statement: Not applicable.

Data Availability Statement: Data are available upon request.

Conflicts of Interest: The authors declare no conflict of interest.

\section{References}

1. Bennett, J.W.; Klich, M. Mycotoxins. Clin. Microbiol. Rev. 2003, 16, 497-516. [CrossRef] [PubMed]

2. Aichinger, G.; Favero, G.; Del Warth, B.; Marko, D. Alternaria toxins-Still emerging? Compr. Rev. Food Sci. Food Saf. 2021, 20, 4390-4406. [CrossRef]

3. Fehr, M.; Pahlke, G.; Fritz, J.; Christensen, M.O.; Boege, F.; Altemöller, M.; Podlech, J.; Marko, D. Alternariol acts as a topoisomerase poison, preferentially affecting the II $\alpha$ isoform. Mol. Nutr. Food Res. 2009, 53, 441-451. [CrossRef]

4. Puntscher, H.; Aichinger, G.; Grabher, S.; Attakpah, E.; Krüger, F.; Tillmann, K.; Motschnig, T.; Hohenbichler, J.; Braun, D.; Plasenzotti, R.; et al. Bioavailability, metabolism, and excretion of a complex Alternaria culture extract versus altertoxin II: A comparative study in rats. Arch. Toxicol. 2019, 93, 3153-3167. [CrossRef]

5. Solhaug, A.; Vines, L.L.; Ivanova, L.; Spilsberg, B.; Holme, J.A.; Pestkab, J.; Collins, A.; Eriksen, G.S. Mechanisms involved in alternariol-induced cell cycle arrest. Mutat. Res._Fundam. Mol. Mech. Mutagen. 2012, 738-739, 1-11. [CrossRef] 
6. Solhaug, A.; Wisbech, C.; Christoffersen, T.E.; Hult, L.O.; Lea, T.; Eriksen, G.S.; Holme, J.A. The mycotoxin alternariol induces DNA damage and modify macrophage phenotype and inflammatory responses. Toxicol. Lett. 2015, 239, 9-21. [CrossRef] [PubMed]

7. Grover, S.; Lawrence, C.B. The Alternaria alternata mycotoxin alternariol suppresses lipopolysaccharide-induced inflammation. Int. J. Mol. Sci. 2017, 18, 1577. [CrossRef]

8. Stypuła-Trębas, S.; Minta, M.; Radko, L.; Jedziniak, P.; Posyniak, A. Nonsteroidal mycotoxin alternariol is a full androgen agonist in the yeast reporter androgen bioassay. Environ. Toxicol. Pharmacol. 2017, 55, 208-211. [CrossRef] [PubMed]

9. Lehmann, L.; Wagner, J.; Metzler, M. Estrogenic and clastogenic potential of the mycotoxin alternariol in cultured mammalian cells. Food Chem. Toxicol. 2006, 44, 398-408. [CrossRef]

10. Aichinger, G.; Krüger, F.; Puntscher, H.; Preindl, K.; Warth, B.; Marko, D. Naturally occurring mixtures of Alternaria toxins: Anti-estrogenic and genotoxic effects in vitro. Arch. Toxicol. 2019, 93, 3021-3031. [CrossRef]

11. Reuter, S.; Gupta, S.C.; Chaturvedi, M.M.; Aggarwal, B.B. Oxidative stress, inflammation, and cancer: How are they linked? Free Radic. Biol. Med. 2011, 49, 1603-1616. [CrossRef]

12. Udensi, U.K.; Tchounwou, P.B. Oxidative stress in prostate hyperplasia and carcinogenesis. J. Exp. Clin. Cancer Res. 2016, 35, 1-19. [CrossRef] [PubMed]

13. Xie, J.; Kusnadi, E.P.; Furic, L.; Selth, L.A. Regulation of mRNA Translation by Hormone Receptors in Breast and Prostate Cancer. Cancers 2021, 13, 3254. [CrossRef]

14. Božović, A.; Mandušić, V.; Todorović, L.; Krajnović, M. Estrogen Receptor Beta: The Promising Biomarker and Potential Target in Metastases. Int. J. Mol. Sci. 2021, 22, 1656. [CrossRef] [PubMed]

15. Aichinger, G.; Dellafiora, L.; Pantazi, F.; Del Favero, G.; Galaverna, G.; Dall'Asta, C.; Marko, D. Alternaria toxins as casein kinase 2 inhibitors and possible consequences for estrogenicity: A hybrid in silico/in vitro study. Arch. Toxicol. 2020, 94, $2225-2237$. [CrossRef]

16. Kowalska, K.; Habrowska-Górczyńska, D.E.; Urbanek, K.A.; Domińska, K.; Sakowicz, A.; Piastowska-Ciesielska, A.W. Estrogen receptor $\beta$ plays a protective role in zearalenone-induced oxidative stress in normal prostate epithelial cells. Ecotoxicol. Environ. Saf. 2019, 172, 504-513. [CrossRef]

17. Kowalska, K.; Habrowska-Górczyńska, D.E.; Domińska, K.; Urbanek, K.A.; Piastowska-Ciesielska, A.W. ERß and NFkBmodulators of zearalenone-induced oxidative stress in human prostate cancer cells. Toxins 2020, 12, 199. [CrossRef] [PubMed]

18. Kollarova, J.; Cenk, E.; Schmutz, C.; Marko, D. The mycotoxin alternariol suppresses lipopolysaccharide-induced inflammation in THP-1 derived macrophages targeting the NF-кB signalling pathway. Arch. Toxicol. 2018, 92, 3347-3358. [CrossRef] [PubMed]

19. Arcella, D.; Eskola, M.; Gómez Ruiz, J.A. Dietary exposure assessment to Alternaria toxins in the European population. EFSA J. 2016, $14,4654$.

20. Solhaug, A.; Eriksen, G.S.; Holme, J.A. Mechanisms of Action and Toxicity of the Mycotoxin Alternariol: A Review. Basic Clin. Pharmacol. Toxicol. 2016, 119, 533-539. [CrossRef]

21. Ricke, W.A.; McPherson, S.J.; Bianco, J.J.; Cunha, G.R.; Wang, Y.; Risbridger, G.P. Prostatic hormonal carcinogenesis is mediated by in situ estrogen production and estrogen receptor alpha signaling. FASEB J. 2008, 22, 1512-1520. [CrossRef]

22. Christoforou, P.; Christopoulos, P.F.; Koutsilieris, M. The role of estrogen receptor $\beta$ in prostate cancer. Mol. Med. 2014, 20, 427-434. [CrossRef]

23. Miró, A.M.; Sastre-Serra, J.; Pons, D.G.; Valle, A.; Roca, P.; Oliver, J. 17 $\beta$-Estradiol regulates oxidative stress in prostate cancer cell lines according to ERalpha/ERbeta ratio. J. Steroid Biochem. Mol. Biol. 2011, 123, 133-139. [CrossRef]

24. Aichinger, G.; Beisl, J.; Marko, D. Genistein and delphinidin antagonize the genotoxic effects of the mycotoxin alternariol in human colon carcinoma cells. Mol. Nutr. Food Res. 2017, 61, 1600462. [CrossRef]

25. Fernández-Blanco, C.; Font, G.; Ruiz, M.J. Oxidative DNA damage and disturbance of antioxidant capacity by alternariol in Caco-2 cells. Toxicol. Lett. 2015, 235, 61-66. [CrossRef] [PubMed]

26. Tiessen, C.; Fehr, M.; Schwarz, C.; Baechler, S.; Domnanich, K.; Böttler, U.; Pahlke, G.; Marko, D. Modulation of the cellular redox status by the Alternaria toxins alternariol and alternariol monomethyl ether. Toxicol. Lett. 2013, 216, 23-30. [CrossRef]

27. Kowalska, K.; Habrowska-Górczyńska, D.E.; Kozieł, M.J.; Urbanek, K.A.; Domińska, K.; Piastowska-Ciesielska, A.W. Mycotoxin alternariol (AOH) affects viability and motility of mammary breast epithelial cells. Int. J. Mol. Sci. 2021, 22, 696. [CrossRef]

28. Chotiner, J.Y.; Wolgemuth, D.J.; Wang, P.J. Functions of cyclins and CDKs in mammalian gametogenesis. Biol. Reprod. 2019, 101, 591-601. [CrossRef] [PubMed]

29. Huang, B.; Chen, Q.; Wang, L.; Gao, X.; Zhu, W.; Mu, P.; Deng, Y. Aflatoxin b1 induces neurotoxicity through reactive oxygen species generation, dna damage, apoptosis, and s-phase cell cycle arrest. Int. J. Mol. Sci. 2020, 21, 6517. [CrossRef] [PubMed]

30. Mak, P.; Li, J.; Samanta, S.; Mercurio, A.M. ERB2 regulation of NF-kB activation in prostate cancer is mediated by HIF-1. Oncotarget 2015, 6, 40247-40254. [CrossRef] [PubMed]

31. Kresse, H.; Schnherr, E. Proteoglycans of the extracellular matrix and growth control. J. Cell. Physiol. 2001, 189, 266-274. [CrossRef]

32. Cancemi, P.; Aiello, A.; Accardi, G.; Caldarella, R.; Candore, G.; Caruso, C.; Ciaccio, M.; Cristaldi, L.; Di Gaudio, F.; Siino, V.; et al. The Role of Matrix Metalloproteinases (MMP-2 and MMP-9) in Ageing and Longevity: Focus on Sicilian Long-Living Individuals (LLIs). Mediat. Inflamm. 2020, 2020, 1-11. [CrossRef] 
33. Leung, Y.-K.; Lam, H.-M.; Wu, S.; Song, D.; Levin, L.; Cheng, L.; Wu, C.-L.; Ho, S.-M. Estrogen receptor $\beta 2$ and $\beta 5$ are associated with poor prognosis in prostate cancer, and promote cancer cell migration and invasion. Endocr. Relat. Cancer 2010, 17, 675. [CrossRef]

34. Powell, I.J.; Chinni, S.R.; Reddy, S.S.; Zaslavsky, A.; Gavande, N. Pro-inflammatory cytokines and chemokines initiate multiple prostate cancer biologic pathways of cellular proliferation, heterogeneity and metastasis in a racially diverse population and underlie the genetic/biologic mechanism of racial disparity: Update. Urol. Oncol. Semin. Orig. Investig. 2021, 39, 34-40.

35. Schmutz, C.; Cenk, E.; Marko, D. The Alternaria Mycotoxin Alternariol Triggers the Immune Response of IL-1 $\beta$-stimulated, Differentiated Caco-2 Cells. Mol. Nutr. Food Res. 2019, 63, e1900341. [CrossRef]

36. Erb, H.H.H.; Langlechner, R.V.; Moser, P.L.; Handle, F.; Casneuf, T.; Verstraeten, K.; Schlick, B.; Schäfer, G.; Hall, B.; Sasser, K.; et al. IL6 sensitizes prostate cancer to the antiproliferative effect of IFN $\alpha 2$ through IRF9. Endocr. Relat. Cancer 2013, 20, 677-689. [CrossRef]

37. Handle, F.; Puhr, M.; Schaefer, G.; Lorito, N.; Hoefer, J.; Gruber, M.; Guggenberger, F.; Santer, F.; Marques, R.B.; van Weerden, W.M.; et al. The STAT3 inhibitor galiellalactone reduces IL6-mediated AR activity in benign and malignant prostate models. Mol. Cancer Ther. 2018, 17, 2722-2731. [CrossRef]

38. Xiao, L.; Luo, Y.; Tai, R.; Zhang, N. Estrogen receptor $\beta$ suppresses inflammation and the progression of prostate cancer. Mol. Med. Rep. 2019, 49, 3555-3563. [CrossRef]

39. Bansal, M.; Singh, N.; Alam, S.; Pal, S.; Satyanarayana, G.N.V.; Singh, D.; Ansari, K.M. Alternariol induced proliferation in primary mouse keratinocytes and inflammation in mouse skin is regulated via PGE2/EP2/cAMP/p-CREB signaling pathway. Toxicology 2019, 412, 79-88. [CrossRef]

40. Del Favero, G.; Mayer, R.M.; Dellafiora, L.; Janker, L.; Niederstaetter, L.; Dall'Asta, C.; Gerner, C.; Marko, D. Structural Similarity with Cholesterol Reveals Crucial Insights into Mechanisms Sustaining the Immunomodulatory Activity of the Mycotoxin Alternariol. Cells 2020, 9, 847. [CrossRef]

41. Dellafiora, L.; Warth, B.; Schmidt, V.; Del Favero, G.; Mikula, H.; Fröhlich, J.; Marko, D. An integrated in silico/in vitro approach to assess the xenoestrogenic potential of Alternaria mycotoxins and metabolites. Food Chem. 2018, 248, 253-261. [CrossRef] 